\title{
Effects of Internet Users' Perception Regarding the Risks and Benefits of the Internet on Cyberspace Trust ${ }^{1}$
}

\author{
Wookjoon Sung $^{1}$ and Dongwook Kim ${ }^{2}$ \\ ${ }^{1}$ Graduate School of Public Policy \& Infomation Tech., Seoul National University \\ of Science \&Technology \\ 232 Gongneung-ro, Nowon-gu, Seoul, 139-743, Korea, \\ ${ }^{2}$ Graduate School of Public Administration, Seoul National University \\ 1 Gwanak-ro, Gwank-gu, Seoul 151-742, Korea \\ ${ }^{1}$ wjsung@seoultech.ac.kr \\ ${ }^{2}$ Corresponding Author:dong@snu.ac.kr
}

\begin{abstract}
The paper is an exploratory research concerning information trust on cyberspace. The research question is presented as, "How do individuals' perceptions regarding the benefits and risks of the internet affect their trust in cyberspace?" Dependent variables used in the study consisted of trust in online information. Explanatory variables consisted of sociodemographic characteristics (gender, age, education level, income level, employment status), internet usage pattern (frequency of use, online behavior, means of getting online), and perception of the internet (benefits, risks, attitude towards the online environment, internet ethics). Positive perception including perception of the benefits of the internet, positive expectation for online environment, and online ethics contributed more significantly to cyberspace trust than more than negative view of the internet or negative expectation for the internet.
\end{abstract}

Keywords: Information Reliability, Information Trust, Online Trust, Information Culture, Perception of the internet

\section{Introduction}

Humans exist in two spaces today: the off-line space that we have occupied throughout history is thousands of years old, while the online space has only been created within the last 30 years or so with the advent of the internet. Although the online space is still considered a mere extension or a part of the off-line space, there is no doubt that the online space has affected our lives with increasing intensity with the dawn of the smart era. Mass adoption of smart devices and wireless internet has rung in the arrival of a hyper-connected era, where access to the online world is made possible anytime and anywhere. Advances in the Internet of Things (IoT), wearable computers, and $\mathrm{O} 2 \mathrm{O}$, in fact, has blurred the line between the online world and the off-line world.

There was a time when the amount of information was directly correlated with the level of knowledge. Internet progress allowed us improved access to information at an affordable cost. Unfortunately, we are currently lost in this sea of information. Against this deluge of information, we began turning our attention to the quality of information rather than its quantity, and our desire for reliable information has grown. There are no absolute standards against which to assess "trust," as it is a relational concept existing deep within individuals' perception or at the core of a culture. Then, how much does our society trust the information available online? And just what influences the level of trust?

1 This work was supported by the National Research Foundation of Korea Grant funded by the Korean Government (NRF-2014S1A3A2044645) 
The current paper is an exploratory research concerning cyberspace trust as information culture in the internet era. Discussions pertaining to the internet era and online sources' reliability have been ongoing since the widespread adoption of smart devices and resulting information overload. However, no empirical research that looks at the factors influencing our trust in online information as part of information culture is currently available. In a normative sense, trust is rooted in one's belief in and respect towards others. In a heuristic sense, it is associated with one's perception regarding the benefits and risks of online information. Trust can be enhanced through implementation of appropriate institutional tools. In an online context, however, it is more effective to cultivate a culture of trust through individuals' voluntary behaviors and relationships, as opposed to institutional intervention. On this note, the current paper seeks to analyze how internet users' attitude towards respect for others and normative response behaviors (normative factor) as well as how their perception regarding benefits and risks associated with the internet (heuristics factor) may affect their trust in online information. Such an epistemological discussion regarding users' trust in online information will allow a more macroscopic view of cyberspace and provide an opportunity to continue the conversation from a sociocultural point of view.

\section{Literature Review}

\subsection{Trusting Cyberspace Information}

The notion of trust is discussed at varying levels by scholars. The term itself is closely associated with various other synonyms such as trustworthiness, well-intentioned, truthful, and unbiased $[4,12,13,16]$. Trust may also be measured in various forms at a relational level between objects, individuals, societies, communities, and governments. It can also be classified in a variety of ways depending on the purpose of research, such as social trust [19], personal trust vs. social trust [5, 8, 24], trust for media, trust for products and brands, and trust for government. Trust garners attention from a variety of research fields because it is known to have a positive effect on both the agent and recipient, albeit indirectly. According to existing research findings, trust has a positive effect on individuals and organizations alike. At an individual level, trust positively affects a persons' subjective emotions, sense of happiness, performance, and organizational commitment [22, 25]. At an organizational level, trust facilitates participation and cooperation, which in turn contributes to overall political and economic progress of the organization $[2,18]$. The common thread found in much scholastic research is that trust is a perceived quality $[3,28]$. According to scholars, trust is not inherently present in its recipient or information itself, but rather emerges upon being perceived by a person.

The biggest issue regarding trust in cyberspace today has to do with reliability of online information. While cyberspace is viewed as a constructive space being shaped through interactivity with the real world in the context of society and culture [1], reliability of cyberspace information is being questioned more than ever before. At the core of such skepticism lies the distrust of internet resources. Since stepping into the information era, our society's information culture paradigm has shifted from access to information (the 1990s), digital inequality (the 2000s), and finally, to reliability of information resources (the 2010s) (Kim, 2007). In our current smart era characterized by hyper-connectivity, the speed at which information is produced, distributed, and reproduced continues to increase.

On the other hand, it is becoming increasingly more difficult to discern what information is truly needed, while distorted and biased information is emerging as a new social problem. Official data published by government and public institutions used to be regarded as the most reliable source of information. In recent years, however, what "may" be present on the other side of information as the truth has stirred people's curiosity. The 
reliability of news reports is being threatened with the growing number of internet media. Furthermore, the media's monopoly over supply of information is no longer a reality. Internet progress and the introduction of smart devices allowed internet users to produce and transmit information on their own. It has become common to exchange information through SNS including blogs, mini-hompi (homepages), Facebook, Twitter, and so forth. However, information provided by general internet users does not guarantee quality or credibility. In fact, rather than high-quality and credible information, the exchange of gossip-based information is all too prevalent. Such information may be fun but hardly reliable. Further, although our trust in the traditional sources of information is weakening, the reality is that increasing user participation in information supply does not appear to resolve the trust issue.

\subsection{Factors Associated with Cyberspace Trust}

In general, the operational definition and measurement index of trust can vary widely in empirical research, depending on whether the analysis unit is individuals or organizations [29]. As for research concerning individuals, factors influencing trustforming and increased/decreased trust are typically found in the respondents' individual characteristics [29, 27, 31]. Factors primarily used in many on-/off-line empirical studies on trust are demographic variables such as gender, age, education level, income level, and occupation. Studies on trust that concern individuals have been using diversity, expertise, and transparency of the constituents as variables, in addition to the demographic variables mentioned above.

On the other hand, along with the growing scope and importance of the online space, the number of studies that look at the factors influencing trust in cyberspace has increased recently. These studies empirically test the issues pertaining to cyberspace trust with a general focus on the internet media's characteristics and user behavior. While research examining the relationship between media and trust used to focus on the internet usage rate, it has evolved to turn its focus on the internet usage pattern [15, 26, 30, 32, 34]. According to research, it is still difficult to conclude a particular correlation between media usage rate and trust. Nevertheless, research found that internet use for purposes of information exchange had a positive influence on cyberspace trust, whereas internet use for purposes of entertainment had a negative influence [14, 15, 23, 30, 32, 34].

As previously discussed, if focusing on the cognitive attributes of trust, we need to examine individuals' view of cyberspace, experiential perception, and perceived expectations, in addition to sociodemographic characteristics and media usage pattern. Discussions on cyberspace have much to do with individuals' fundamental perspectives regarding information technology. The different views held by technological determinism and social determinism regarding information technology have been discussed since the beginning of discussions on the internet $[7,9,10,11,20,21]$. Technological determinism is linked to positive views and opinions of information technology and the internet. On the other hand, social determinism has been interpreting advances in information technology and its wide adoption from a critical point of view. Along with these views, a conciliatory view has also emerged, which defers judgment while taking into account the sociocultural context of the time as well as potential institutional and policy reform. Such discussions that are based on fundamental views of information technology are essential elements for describing a concept that forms over time, such as trust. For instance, internet ethics based on users' general perceptions of internet use, current usage environment, and reciprocal norms is closely associated with cyberspace trust. 


\section{Research Method}

\subsection{Research Questions and Hypotheses}

The current paper reviews the factors influencing trust in cyberspace to help create effective policy measures that address the issue. While existing studies on cyberspace trust have focused on individual characteristics and internet use pattern, the current study focuses on the factors pertaining to users' perception of the cyberspace as important variables. In this vein, our research question is presented as, "How do individuals' perceptions regarding the benefits and risks of the internet affect their trust in cyberspace?" Perception-based factors as explanatory variables are further distinguished into general views of the internet and expectation based on the assessment of current cyberspace environment.

Hypothesis 1.1 Individuals who perceive a greater level of benefits offered by the internet will have a greater level of trust in cyberspace than those who do not.

Hypothesis 1.2 Individuals who perceive a greater level of threat imposed by problems in the internet sphere will have a lower level of trust in online information and websites.

Hypothesis 1.3 Individuals with a greater level of positivity towards today's user environment will have a greater level of trust in cyberspace than those who do not.

Hypothesis 1.4 Individuals with a greater level of positivity towards today's user environment will have a lower level of trust in online information and websites

\subsection{Survey Design and Measuring of Key Variables}

For the current study, the raw data collected by the 2013 National Information Culture Survey published by the National Information Society Agency in 2015 were used. The survey was conducted between November and December of 2013 regarding the internet users across Korea aged six years and older, via individual interviews on visitation. Using the August 2013 Permanent Resident Population Estimate data and the 2012 Internet Usage Survey as a sampling framework, study samples were extracted with the multistage cluster/area sampling method (by city/province, by dong/eub/myun, by gender, by age). The total number of samples was 4,650 individuals from 17 cities and provinces.

Dependent variables used in the study consisted of trust in online information. Explanatory variables consisted of sociodemographic characteristics (gender, age, education level, income level, employment status), internet usage pattern (frequency of use, online behavior, means of getting online), and perception of the internet (benefits, risks, attitude towards the online environment, internet ethics). The questionnaire mostly consisted of self-assessment items measured on a 5-point scale (strongly disagree, fairly disagree, neutral, fairly agree, strongly agree). In addition, the key variables were selected upon an item factor analysis. The key variables and measurement items are presented in $<$ Table $1>$. 
Table 1. Main Variables and Measurements

\begin{tabular}{|c|c|c|}
\hline Variables & Measurement items & Measurement \\
\hline $\begin{array}{l}\text { Dependent } \\
\text { variable }\end{array}$ & $\begin{array}{l}\text { (trust in online information) } \\
\text { How much do you trust the following types of online } \\
\text { information? } \\
\text { 1) Online shopping malls, private businesses' } \\
\text { products/services } \\
\text { 2) Government/public agency notices and advertisements } \\
\text { 3) Media reports, news } \\
\text { 4) Information circulating SNS } \\
\text { 5) Other online information }\end{array}$ & $\begin{array}{l}\text { 5-point scale } \\
\text { Factor analysis }\end{array}$ \\
\hline $\begin{array}{l}\text { Normative } \\
\text { factor }\end{array}$ & $\begin{array}{l}\text { (respect for others) } \\
\text { How much do you agree with the following statements? } \\
\text { 1) Even those who do not share my opinion have the } \\
\text { rights to express their opinions } \\
\text { 2) I need to listen to other people's opinions as well } \\
\text { 3) There are opinions of others that are worth accepting } \\
\text { 4) Other people's online complaints or petitions should } \\
\text { also be allowed }\end{array}$ & $\begin{array}{l}\text { 5-point scale } \\
\text { Factor analysis }\end{array}$ \\
\hline \multirow[b]{2}{*}{$\begin{array}{l}\text { Heuristic } \\
\text { factor } 1\end{array}$} & $\begin{array}{l}\text { (perception regarding the risks associated with internet } \\
\text { use) } \\
\text { How serious do you think the following problems are? } \\
\text { 1) Unauthorized use of personal information } \\
\text { 2) Personal attack and slander } \\
\text { 3) Unauthorized use of contents } \\
\text { 4) Transmission of unhealthy/harmful information } \\
\text { 5) Bullying }\end{array}$ & \multirow[b]{2}{*}{$\begin{array}{l}\text { 5-point scale } \\
\text { Factor analysis }\end{array}$} \\
\hline & $\begin{array}{l}\text { (perception regarding the benefits of internet use) } \\
\text { How much do you agree with the following statements? } \\
\text { 1) Increased access to news and other information } \\
\text { pertaining to current affairs. } \\
\text { 2) I am reading more now than when I used to read on } \\
\text { paper only. } \\
\text { 3) Increased opportunities for self-expression. } \\
\text { 4) Increased online activities such as online shopping and } \\
\text { reservation. } \\
\text { 5) My culture/entertainment life has become richer. } \\
\text { 6) Increased opportunities to meet and exchange with new } \\
\text { people. } \\
\text { 7) A day without access to the internet would be } \\
\text { extremely inconvenient. } \\
\text { 8) I like trying new apps and other internet services. }\end{array}$ & \\
\hline
\end{tabular}




\begin{tabular}{|c|c|c|}
\hline \multirow{2}{*}{$\begin{array}{l}\text { Perception } \\
\text { regarding } \\
\text { the online } \\
\text { environme } \\
\text { nt }\end{array}$} & $\begin{array}{l}\text { (negative expectation) } \\
\text { 1) It makes me uneasy when I'm required to submit my } \\
\text { personal information such as my social security number } \\
\text { online for membership registration purposes, etc. } \\
\text { 3) The level of slander, cussing, and negative exposure is } \\
\text { at a serious level. } \\
\text { 4) Punishment for cyberbullying must be enhanced. } \\
\text { 7) A great deal of online bulletin and news reports are } \\
\text { fake or distorted. } \\
\text { 8) False information and truth distortion in cyberspace } \\
\text { will become worse in the future. }\end{array}$ & \multirow{2}{*}{$\begin{array}{l}\text { 5-point scale } \\
-\quad \text { Factor } \\
\text { analysis } \\
\text { Factor 1: } \\
1,3,4,7,8 \\
\text {. Factor 2: } \\
2,5,6,8\end{array}$} \\
\hline & $\begin{array}{l}\text { (positive expectation) } \\
\text { 2) Personal information can sufficiently be protected if } \\
\text { users themselves take precautions. } \\
\text { 5) Tightening regulations for cyberspace violence may } \\
\text { negatively impact freedom of expression. } \\
\text { 6) Information supplied by famous individuals, including } \\
\text { power bloggers, is credible. } \\
\text { 8) Comments and the number of recommend/do not } \\
\text { recommend reflect the opinion of the general public. }\end{array}$ & \\
\hline $\begin{array}{l}\text { Frequency } \\
\text { of internet } \\
\text { use }\end{array}$ & $\begin{array}{l}\text { Daily }=1,4-5 \text { days } / \text { week }=2,3-4 \text { days } / \text { week }=3,1-2 \\
\text { days } / \text { week }=4,1 \text { or more days/month }=5 \text {, less than } 1 \\
\text { day } / \text { month }=6\end{array}$ & \\
\hline $\begin{array}{l}\text { Internet } \\
\text { use }\end{array}$ & $\begin{array}{l}(\text { PC/laptop) no }=0, \text { yes }=1 \\
(\text { smart device }) \text { no }=0, \text { yes }=1\end{array}$ & \\
\hline $\begin{array}{l}\text { Internet } \\
\text { usage } \\
\text { pattern }\end{array}$ & $\begin{array}{l}\text { How much of the following activities do you engage in } \\
\text { online? } \\
\text { 1) Posting posts and comments } \\
\text { 2) Posting photos and videos } \\
\text { 3) Sharing/delivering content } \\
\text { 4) Online finance activity such as banking and stock } \\
\text { exchange } \\
\text { 5) Online shopping (purchases, reservations, etc.) } \\
\text { 6) Submitting requests for/receiving copies of social } \\
\text { security number and other civil documents } \\
\text { 7) Internet cafes, internet community activity } \\
\text { 8) SNS use including mini-hompi, blogs, Facebook, } \\
\text { Twitter } \\
\text { 9) Instant messaging including MSN, Nate On, Kakaotalk, } \\
\text { etc. }\end{array}$ & $\begin{array}{l}\text { 5-point scale } \\
\text { Factor analysis }\end{array}$ \\
\hline Age & $\begin{array}{l}1=\sim 6,2=10-19,3=20-29,4=30-39 \\
5=40-49,6=50-59,7=60-69,8=70 \text { and older }\end{array}$ & \\
\hline Gender & Female $=0$, male $=1$ & \\
\hline $\begin{array}{l}\text { Employme } \\
\text { nt }\end{array}$ & Unemployed $=0$, employed $=1$ & \\
\hline
\end{tabular}




\begin{tabular}{|c|c|}
\hline $\begin{array}{l}\text { Education } \\
\text { level }\end{array}$ & $\begin{array}{l}\text { Middle school degree or less }=1 \text {, high school degree }=2 \text {, } \\
\text { college degree }=3 \text {, graduate school degree or more }=4\end{array}$ \\
\hline $\begin{array}{l}\text { Household } \\
\text { income }\end{array}$ & $\begin{array}{l}1=\mathrm{KRW} 1 \text { million or less, } 2=\mathrm{KRW} 1-2 \text { million, } 3= \\
\text { KRW } 2-3 \text { million, } 4=\mathrm{KRW} 3-4 \text { million, } 5=\mathrm{KRW} 4-5 \\
\text { million, } 6=\mathrm{KRW} 5-6 \text { million, } 7=\mathrm{KRW} 6-7 \text { million, } 8= \\
\mathrm{KRW} 7-8 \text { million, } 9=\mathrm{KRW} 8-9 \text { million, } 10=\mathrm{KRW} 9-10 \\
\text { million, } 11=\mathrm{KRW} 10 \text { million or more }\end{array}$ \\
\hline
\end{tabular}

\subsection{Method of Analysis}

For the analysis, a descriptive statistics regarding the key variables, a factor analysis to verify the scales' validity and reliability, and a multiple regression analysis to examine the causal relationship were performed. SPSS 22.0, a statistics software, was used for all the analyses.

We examine this question through a multiple regression model

$\mathrm{Y}=\alpha 0+\beta 1 \cdot \mathrm{X} 1+\beta 2 \mathrm{X} 2+\beta 3 \mathrm{X} 3+\beta 4 \mathrm{X} 4+\beta 5 \mathrm{X} 5+\beta 6 \mathrm{X} 6+\beta 7 \mathrm{X} 7+\beta 8 \mathrm{X} 8+\beta 9 \mathrm{X} 9+\beta 10 \mathrm{X} 10+\beta 11 \mathrm{X} 11+$

$\beta 12 \mathrm{X} 12+\beta 13 \mathrm{X} 13+\beta 14 \mathrm{X} 14+\beta 15 \mathrm{X} 15$

where the dependent measure $(\mathrm{Y})$ is trust in online information; $\mathrm{X} 1$ is gender; $\mathrm{X} 2$ is age; $\mathrm{X} 3$ is employment; $\mathrm{X} 4$ is income; $\mathrm{X} 5$ is frequency of internet use; $\mathrm{X} 6$ is occupation; $\mathrm{X} 7$ is desktop computer; $\mathrm{X} 8$ is smart device; $\mathrm{X} 9$ is Internet usage pattern 1; and $\mathrm{X} 10$ is Internet usage pattern 2; and X11 is the risks of internet use; and X12 is the benefits of internet use; and X13 is negative expectation; and X14 is positive expectation; and X15 is respect for others.

\section{Analysis Results}

\subsection{Descriptive Statistics}

The following reveals descriptive statistics of the key variables used in the study. The total number of respondents were 4,650, which consisted of 2,186 females (47\%) and 2,464 males $(53 \%)$. As for age distribution, 1,008 respondents $(21.7 \%)$ were 10 years or younger, 1,814 respondents (39\%) were between 20-30 years old, 1,555 respondents (33.4\%) were 40-50 years old, and 273 respondents (5.9\%) were 60 years and older. In terms of education level, 1,012 (21.8\%) respondents had a middle school degree or less, $1,950(41.9 \%)$ respondents had a high school degree, 1,623 (34.9\%) respondents had a college degree, and $54(1.2 \%)$ respondents had a graduate degree or more. As for employment status, 1,940 (41.7\%) respondents were unemployed, while 2,532 (54.4\%) respondents were employed.

The average score of the items measuring the variable "trust in online information" was 3.5 points, while that of "trust in websites" was 3.7 points. The average scores of the explanatory variables were distributed between 1.2 points and 4.3 points.

\subsection{Multiple Regression Analysis}

The current study performed a hierarchical regression analysis in order to examine in steps the influence that the study's explanatory variables (individual characteristics (model 1-1), characteristics of media and usage pattern (model 1-2), perception of the internet (model 1-3)) exerted on internet users' trust in online information. Firstly, results of a variance analysis indicated that the model's $F$ value and significance probability were statistically significant, which produced a regression line that is fit for the study model. 
The models' R2 (modified R2) were compared to examine their explanatory power. Model 1 had an R2 of 0.005 (0.003), model 2 had an R2 of 0.015 (0.012), and model 3 had an R2 of 0.132 (0.129), indicating a notable jump in model 3. All variables' VIFs were less than 10 , indicating multicollinearity.

Let us take a look at the regression analysis results with a focus on model 3. Of the individual characteristics, gender, age, and income level were found significant. Secondly, of the variables pertaining to the means of getting online and usage pattern, owning a device and transactional use were found to be significant. Thirdly, variables pertaining to users' perception of the internet, which include benefit perception, risk perception, perception regarding the online environment, and internet ethics (respect for others), were found to be significant.

As for the hypotheses pertaining to trust in cyberspace and associated perception-based factors, all hypotheses were accepted, and the standard coefficients proved to be higher than other factor variables. Comparison of standardized coefficients $(\beta)$ indicated that, more than negative view of the internet (-.052) or negative expectation for the internet (0.86), positive perception including perception of the benefits of the internet $(0.183)$, positive expectation for online environment $(0.179)$, and online ethics $(0.184)$ contributed more significantly to cyberspace trust. Detailed results of the regression analysis are presented in $\langle$ Table 2$\rangle$.

\begin{tabular}{|c|c|c|c|c|}
\hline & & Model 1 & Model 2 & Model 3 \\
\hline & & $\begin{array}{l}\text { Standardized } \\
\text { Coef. } \\
\text { (S.E) }\end{array}$ & $\begin{array}{l}\text { Standardized } \\
\text { Coef. } \\
\text { (S.E) }\end{array}$ & $\begin{array}{l}\text { Standardized } \\
\text { Coef. } \\
\text { (S.E) }\end{array}$ \\
\hline & Gender & -.029 & $-.035^{* *}$ & $-.046 * * *$ \\
\hline & r teenage & $\begin{array}{l}-.023 \\
(.048)\end{array}$ & $\begin{array}{l}-.048^{* *} \\
(.051)\end{array}$ & $\begin{array}{l}-.041^{* *} \\
(.048)\end{array}$ \\
\hline $\begin{array}{c}\text { Age } \\
\text { (vs 20s) }\end{array}$ & $40 s \sim 50 s$ & $\begin{array}{l}.001 \\
(.036)\end{array}$ & $\begin{array}{l}.004 \\
(.038)\end{array}$ & $\begin{array}{l}.016 \\
(.036)\end{array}$ \\
\hline & 60 s and older & $\begin{array}{l}-.017 \\
(.065)\end{array}$ & $\begin{array}{l}-.022 \\
(.072)\end{array}$ & $\begin{array}{l}-.010 \\
(.068)\end{array}$ \\
\hline & Employment & $\begin{array}{l}.032 \\
(.056)\end{array}$ & $\begin{array}{l}.036 \\
(.056)\end{array}$ & $\begin{array}{l}.046 \\
(.052)\end{array}$ \\
\hline Househ & old income(monthly) & $\begin{array}{l}.077 * * * \\
.001)\end{array}$ & $\begin{array}{l}.073 * * * \\
(.001)\end{array}$ & $\begin{array}{l}.054 * * \\
.001)\end{array}$ \\
\hline Frequ & ency of internet use & & $\begin{array}{l}-.029 \\
(.014)\end{array}$ & $\begin{array}{l}.006 \\
.014)\end{array}$ \\
\hline & PC/laptop & & $\begin{array}{l}.067 * * * \\
.085)\end{array}$ & $\begin{array}{l}.033 * * \\
(.080)\end{array}$ \\
\hline & smart device & & $\begin{array}{l}-.057 * * * \\
(.060)\end{array}$ & $\begin{array}{l}-.057 * * * \\
(.056)\end{array}$ \\
\hline $\begin{array}{l}\text { Internet } \\
\text { usage }\end{array}$ & $\begin{array}{c}\text { communication/contents } \\
\text { sharing }\end{array}$ & & $\begin{array}{l}-.032 \\
(.017)\end{array}$ & $\begin{array}{l}.008 \\
(.016)\end{array}$ \\
\hline pattern & shopping/finance & & $\begin{array}{l}.047 * * * \\
(.017)\end{array}$ & $\begin{array}{l}.042 * * \\
(.016)\end{array}$ \\
\hline $\begin{array}{l}\text { Heuristic } \\
\text { factors }\end{array}$ & the risks of internet use & & & $\begin{array}{l}-.052 * * * \\
(.015)\end{array}$ \\
\hline
\end{tabular}




\begin{tabular}{|c|c|c|c|c|}
\hline & $\begin{array}{l}\text { the benefits of internet } \\
\text { use }\end{array}$ & & & $\begin{array}{l}.183^{* * * *} \\
(.016)\end{array}$ \\
\hline \multirow{2}{*}{$\begin{array}{c}\text { online } \\
\text { environment }\end{array}$} & negative expectation & & & $\begin{array}{l}-.086^{* * *} \\
(.015)\end{array}$ \\
\hline & positive expectation & & & $\begin{array}{l}.179 * * * \\
(.015)\end{array}$ \\
\hline \multirow{2}{*}{\multicolumn{2}{|c|}{$\begin{array}{l}\text { Normative factor } \\
\text { : respect for others }\end{array}$}} & & & $\begin{array}{l}.184 * * * \\
(.015)\end{array}$ \\
\hline & & $\begin{array}{l}n=4472 \\
R 2=0.005 \\
\text { Adj. } R 2=0.003 \\
F=3.506 \\
P \text { rob }>F=0.002\end{array}$ & $\begin{array}{l}\mathrm{n}=4472 \\
\mathrm{R} 2=0.015 \\
\text { Adj. } \mathrm{R} 2=0.012 \\
\mathrm{~F}=5.991 \\
\text { Prob }>\mathrm{F}=0.000\end{array}$ & $\begin{array}{l}\mathrm{n}=4472 \\
\mathrm{R} 2=0.132 \\
\text { Adj. } \mathrm{R} 2=0.129 \\
\mathrm{~F}=42.530 \\
\text { Prob }>\mathrm{F}=0.000\end{array}$ \\
\hline & & $* * * p<0.01 * * 1$ & $p<0.05$ & \\
\hline
\end{tabular}

\section{Conclusions}

The current study analyzed the factors influencing internet user's trust in online information. More specifically, the factors affecting cyberspace trust, a form of social capital required for continued progress of the online space, were distinguished into individual characteristics, characteristics of the means used to get online and online behavior, and perceptions regarding the internet for analysis. Next, we will discuss a few policy implications that emerged in the analysis, including that which pertained to perception-based factors.

First, more efforts are needed for policy improvement when it comes to factors pertaining to the online environment. Protection of personal information, prevention of cyber violence/defamation, propagation of false information, and so forth have to do with the cultivation of perception base required for internet use. Effective policies and other institutional measures will produce short-term benefits, and will also contribute to nurturing a healthy online culture in the mid- to long-run.

Second, the fact that internet users under 10 years old reported a lower level of cyberspace trust suggests that schools, families, and the society must continue to educate and promote healthy cyberspace culture. Such efforts become even more critical when considering that the rate of internet use will continue to increase among the young internet users, and further that experience and perception at a malleable age will likely have a long-term effect on cyberspace trust.

Third, it is worth noting that smart device use had a negative effect on the users' cyberspace trust. Smart devices' portability, multi-functionality, and wireless capability allow the users to stay in cyberspace longer and to engage in more diverse activities than before. The fact that smart device users' cyberspace trust is low despite these benefits suggests the need for policies that can foster healthy online culture in the age of smart devices.

Finally, to ensure the continuous progress of the "smart" society, more research conducted from a more fundamental and macroscopic point of view is needed. Research conducted with a long-term view incorporating macroscopic concepts such as social 
capital and trust is necessary. Furthermore, continuous discussions are needed in an effort to establish a more comprehensive policy scope and concept pertaining to cyberspace.

\section{References}

[1] M. Castells, I. Tubella, Sancho T., MID de. Isla and B. Wellman, "Social Structure, Cultural Identity, and Personal Autonomy in the Practice of the Internet: The Network Society in Catalonia", The network society, (2004), pp. 233-248.

[2] P. M. Doney and J. P. Cannon, "An examination of the nature of trust in buyer-seller relationships", The Journal of Marketing, (1997), pp. 35-51.

[3] B. J. Fogg and H. Tseng, "The Elements of Computer Credibility", Proceedings of ACM CHI 99 Conferenc,e on Human Factors in Computing Systems, vol. 1, (1999), pp. 80-87.

[4] H. Gatignon and T. S. Robertson, "Innovative Decision Processes", in T. S. Robertson \& H. H. Kassarjian(Eds.), Handbook of Consumer Behavior. Englewood Cliffs, NJ: Prentice-Hall, (1991).

[5] J. L. Glanville and P. Paxton, "How do we learn to trust? A confirmatory tetrad analysis of the sources of generalized trust", Social Psychology Quarterly, vol. 70, no. 3, (2007), pp. 230-242.

[6] F. Fukuyama, "Trust: The social virtues and the creation of prosperity", New York: Free Press, (1995).

[7] C. J. Hamelink, "Militarization in the information age", Geneva: World Council of Churches, (1986).

[8] N. Hayashi and A. Yosano, “Trust and belief about others”, 理論と方法, vol. 20, no. 1, (2005), pp. 5980 .

[9] I. Miles, H. Rush, K. Turner and J. Bessant, "Information Horizons", Edward Elgar, (1988).

[10] J. Naisbitt, Megatrends, Ten New Directions Transforming Our Lives, New York: Warner Books, (1982).

[11] N. Negroponte, "Being Digital”, London: Coronet, (1996).

[12] R. E. Petty, J. T. Cacioppo and R. Goldman, "Personal involvement as a determinant of argument-based persuasion", Journal of Personality and Social Psychology, vol. 41, no. 5, (1981), pp. 847-855.

[13] Self. C. S., "Credibility", In M. Salwen \& D. Stacks(Eds.), An Integrated Approach to Communication Theory and Research. Mahway, NJ: Erlbaum, (1993).

[14] V. Shah, N. Kwak and D. L. Holbert, "Connecting" and "disconnecting" with civic life: Patterns of Internet use and the production of social capital. Political Communication, vol. 18, no. 2, (2001), pp. 141-162.

[15] D. V. Shah, J. Cho, W. P. Eveland and N. Kwak, "Information and expression in a digital age modeling Internet effects on civic participation", Communication Research, vol. 32, no. 5, (2005), pp. 531-565.

[16] J. B. Stiff, "Persuasiive communication", Guilford Press, (1994).

[17] R. D. Putnam, "Bowling Alone: the callapse and Revival of American Commuity", New York: Simon \& Schuster, (2000).

[18] R. Putnam, "Social capital: Measurement and consequences", Canadian Journal of Policy Research, vol. 2, no. 1, (2001), pp. 41-51.

[19] R. D. Putnam, "Making Democracy Work: Civic Traditions in Modern Italy", Princeton, New Jersey: Princeton University Press, (1993).

[20] A. Toffler, "The Third Wave", New York: Bantam Books, (1980).

[21] A. Toffler, "Powershift: Knowledge, Wealth, and Violence at the Edge of the 21st Century", New York: Bantam, (1991).

[22] Y. Tokuda, S. Fujii and T. Inoguchi, "Individual and country-level effects of social trust on happiness: The Asia barometer survey", Journal of Applied Social Psychology, vol. 40, no. 10, (2010), pp. 25742593.

[23] S. Valenzuela, N. Park and K. F. Kee, "Is there social capital in a social network site?: Facebook use and college students' life satisfaction, trust, and participation1", Journal of Computer-Mediated Communication, vol. 14, no. 4, (2009), pp. 875-901.

[24] P. F. Whiteley, "Economic growth and social capital", Political Studies, vol. 48, no. 3, (2000), pp. $443-$ 466.

[25] D. E. Zand, "Trust and managerial problem solving", Administrative science quarterly, (1972), pp. 229239.

[26] N.-W. Kang, "Citizens' Media Use and their Social Trust: Focusing on their Media Use Time and Patterns", Korea Regional Communication Research Association, Journal of Communication Science, vol. 8, no. 3, (2008), pp. 5-44.

[27] T.-R. Kim, "The Study on the Civic Organization on the Formation of Social Capital", Korean Republic Administration Review, vol. 40, no. 3, (2006), pp. $27-51$.

[28] Y.-K. Kim, "Study on the Influence of Factors That Makes Web Sites Credible", Journal of the Korean Society for Library and Information Science, vol. 41, no. 4, (2007), pp. 93-111.

[29] K. NamKoong, "Policy Studies", Seoul: Bobmunsa, (2012).

[30] Y. Min and I.-H. Joo, "Social Capital and its Democratic Consequences: Effects of Media Uses and Social Capital on Political Interest, Trust, and Participation", Korean Journal of Journalism \& Communication Studies, vol. 51, no. 6, (2007), pp. 190-217. 
[31] H.-B. Park, H.-C. Lee and Y.-S. Jo, "An Analysis on the Properties and Determinants of Trust in Government in Korea", Korean Public Administration Review, vol. 37, no. 3, (2003), pp. 45-67.

[32] J.-w. Rhee, T.-j. Moon and E.-m. Kim, "Social Capital and Qualities of Communication", Cyber communication Academic Society, vol. 19, (2006), pp. 135-172.

[33] J. W. Rhee, E.-M. Kim and T.-J. Moon, "The Communicative Foundation of Social Capital in Korea: Impacts of Media Uses on Trust, Civic Engagement, and Socio-Political Participation", Korean Journal of Journalism \& Communication Studies, vol. 49, no. 3, (2005), pp. 234-261.

[34] W. Sung and D. Kim, "A Study on Information Trust on Cyberspace", Proceedings of the 9th 2016 International Interdisciplinary Workshop Series, Cheju, Korea, (2016) April 20-22.

\section{Authors}

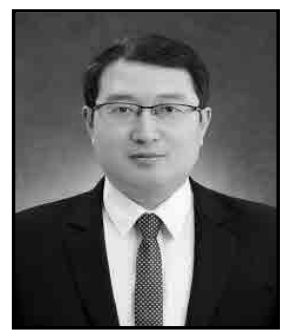

\section{Wookjoon Sung}

Graduate School of Public Policy \& Infomation Tech., Seoul National University of Science \& Technology

Assistant Professor, Ph.D. in Public Administration

Research Interest: ICT Policy, e-Government, Policy Analysis \& Evaluation

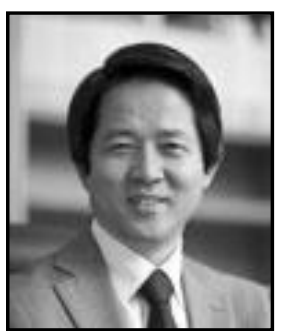

\section{Dongwook Kim}

Graduate School of Public Administration, Seoul National University Dean, Professor, Ph.D. in Public Policy \& Management

Research Interest: Informationization Policy, ICT Policy, Policy Analysis \& Evaluation 
International Journal of Security and Its Applications

Vol. 10, No. 7 (2016) 